\title{
The collaboration of investigative authorities in Tanzania - current issues
}

\author{
By Nina Sokoine*
}

A paper presented on the $4^{\text {th }}$ regional conference on "the requirements for an independent and effective judiciary in Burundi, DR Congo, Kenya, Rwanda, Tanzania and Ugandacurrent problems in criminal and civil proceedings" organised by the Rule of law Program for sub-Saharan Africa of the Konrad-Adenauer-Stiftung (KAS), on $1^{\text {st }}$ to $4^{\text {th }}$ September 2016 in Nairobi, Kenya

\author{
List of Abbreviation \\ CID - Criminal Investigation Department \\ CPA- Criminal Procedure Act \\ DCI- Director of Criminal Investigation \\ DO-CI- District Officer in charge of Criminal Instigation \\ DPC- District Police Commander \\ DPP- Director of Public Prosecution \\ IGP- Inspector General of Police \\ RPC- Regional Police Commander \\ RCO- Regional Crime Officer \\ OCD- Officer Commanding District \\ OCS- Officer Commanding Station
}

\begin{abstract}
This paper discusses the collaboration of investigative authorities in Tanzania. The authority to investigate is primarily vested on the Tanzania Police Force. Apart from the police, there other public authorities with powers to investigate specific offences related to their occupations. However, this paper examines the collaboration of police investigator and public prosecutor.

The police by carrying out the investigative duty assist the prosecutor and the court to dispense justice. The police thus have a duty to collaborate with the prosecutor during the investigation process. However such collaboration is limited to advisory and supervisory role. In Tanzania, the role of Prosecutors in investigation is limited to advisory and supervisory mainly to guide the police investigation to certain direction.
\end{abstract}

* Research Assistant, EACJ. Email: nsokoine@eachq.org or sokoinenina@yahoo.com Mobile: +255 784753564 . 
Inevitably, the collaboration between the two authorities has experienced some conflicting reactions and tendencies which hamper their smooth working relations. Such is experienced in instances where the police after undergoing thorough investigation process they develop a feeling of exclusiveness and feel that the entire investigation domain is their responsibility. As a result any advice or instruction from prosecutors is taken as unnecessary and interference and resistance is shown when told to bring more substantial evidence, amend or improve evidence collected. On the other hand, prosecutors with the academic background they have on human rights, rule of law and due process, develop a more legalistic approach in handling police files. Other things that hampers the working relations between the two authorises include; conflicting views over case disposition, lack of shared common goals and objectivity. Such conflicts are being considered as evidence for a proper functioning of the checks and balance mechanism of the criminal justice system.

To prompt a smooth working relationship between the two, this paper recommends that the police should welcome the checks from prosecutors and the prosecutor's advice to police investigator should always be accompanied with clear and reasonable explanations. Both sides should understand and respect each other's responsibility in criminal procedure. Joint working plans should be developed to promote practical cooperation and build synergy between the two. Further this paper recommends regular meetings that will lead to smooth coordination and simplified investigations. Workshops and seminars should be used to exchange views on areas of contention in order to forge closer working relationship. Both authorities have the core responsibilities of combating crime thus enhanced collaboration is critical.

\section{A. Introduction}

Criminal investigation is an investigation which police officers or other persons have a duty to conduct with a view of ascertaining whether a person should be charged with an offence. ${ }^{1}$ Several other outcomes such as recovering stolen property, deterring individuals from engaging in criminal behaviours and satisfying crime victims have also been associated with the process. ${ }^{2}$

In Tanzania, the authority to investigate is primarily vested on the Tanzania Police Force as provided under section 5 of the Police Force and Auxiliary Services Act, Cap $322 .^{3}$ Apart from the police, there other public authorities with powers to investigate speci-

1 Stroud's Judicial Dictionary of Words and Phrases, (2008), $7^{\text {th }}$ Edition Volume 1 A-E, pg. 605.

2 Police: Criminal Investigations - Criminal Investigation Defined, http://law.jrank.org/pages/1654/P olice-Criminal-Investigations-Criminal-investigation-defined.html, (accessed 11/08/2016).

3 "The force shall be employed in and throughout the United Republic for the preservation of peace, the maintenance of law and order, the prevention of peace, the maintenance of law and order; the prevention and detection of crime, the apprehension and guarding of offenders and the protection of property, and for the performance of all such duties shall be entitled to carry arms.". 
fic offences related to their occupations. However, this paper discusses the collaboration of police investigator and prosecutor only.

The Criminal Procedure Act, [Cap 20 Revised Edition of 2002] gives the police general powers of criminal investigation. These powers include: arrest and search, with or without warrant, interviewing and recording the statements of suspects, remand and commitment, escape and recapture of fugitives and any other powers of law enforcement. These powers are set out in Part II sections 5 to 69 of the CPA.

The duty of the investigator (the police in particular) is to assist the prosecutor and the court to dispense justice. The police thus have a duty to collaborate with the prosecutors and other relevant authorities during the investigation process. The extent or limits of such collaboration is further discussed under part II (C) here below.

\section{B. Investigative Authorities in Tanzania}

This section discusses among other things the functions and administrative structure of the Police Force in Tanzania, the general responsibilities and structure of the Criminal Investigation Department as well as the role of public prosecutors in the investigation process and the extent of their involvement in investigation.

\section{The police: its functions and administrative structure}

The police force in Tanzania are employed in and throughout the Country to among other duties preserve peace, maintain law and order, to prevent and detect crime, apprehend and guard offenders and protect property. 4

The head of the police is Inspector General of Police (IGP). ${ }^{5}$ The IGP is a presidential nominee $^{6}$ charged with the overall command and superintendence of the Tanzania Police Force subject to general directions of the Minister for Home Affairs. In the administration of Police Force, the IGP is assisted by four Commissioners, heading the departments of: Administration and Finance, Operations and Training, Criminal Investigation and the fourth commanding the Police force deployed in Zanzibar. ${ }^{7}$

For administrative purposes, Tanzania is divided into 30 regions and a Regional Police Commander (RPC) is appointed by the IGP to command the Police Officers deployed in

4 Section 5 of the Police Force Ordinance Cap. 322.

5 Official website of the Tanzania Police Force, http://www.policeforce.go.tz/index.php/sw/kuhusu-si si/vyeo-vya-jeshi-la-polisi(Accessed17/08/2016).

6 The President is the chief commander of all armed forces in the country as per Article 33(2) of the United Republic of Tanzania Constitution, 1997 (As amended from time to time). By virtue of being the chief commander of all armed forces in the country he is empowered to appoint the IGP and the four commissioners.

7 Kamau, Evelyn, The police, the people, the politics; police accountability in Tanzania, (2006), (accessed 17/08/2016). 
each region. Each region is further subdivided into a number of districts which are headed by Officers Commanding Districts (OCD) who are appointed by the IGP and answerable to the RPC. Districts have a number of police stations each under their command and an officer of appropriate rank is appointed to command each police station. Such officers are referred to as Officers Commanding Stations (OCS).

\section{The investigation machinery}

As noted earlier, one of the four principal assistants to the IGP is the Commissioner of Police in charge of Criminal Investigation Department (CID) commonly known as the Director of Criminal Investigation (DCI) ${ }^{8}$ who is answerable to the IGP for the proper administration of, and the control of personnel in the Criminal Investigation Department.

The Criminal Investigation Department (CID) is generally responsible to prevent crime, efficiently investigate and detect serious crimes and incidents, collect and collate all information regarding crime in the country so that the IGP and the Government may be kept informed in all matters of criminal interest, maintain close and effective liaison with all branches of the force and, in particular with the General Duties Branch, maintain criminal records and statistics, provide advice and assistance in all investigations giving rise to difficulty or doubt and the legal advice sought as may be necessary. ${ }^{9}$

Criminal Investigation Department (CID) is the organ most concerned with the investigation of crime in Tanzania. It may be instructive to note however that the CID is mostly concerned with the investigation of serious crime and incidents. The CID may thus be said to be a specialized organ for the investigation of serious crimes and incidents. This means that the investigation of minor offences not meriting the classification 'serious' is left to the General Duties Branch of the police.

Serious crimes reported to the police in Tanzania are broadly classified into three main types. These categories are crimes against the person, crimes related to property and crimes against social order. Accidents involving rail, air and all forms of marine transport are also classified as serious incidents. ${ }^{10}$

1. Crimes against the person are those which injure or affect a person. These include homicide, rape, sodomy, infanticide and crimes against children or infants such as child stealing and so forth.

2. Property crimes are those committed for economic or property gain. These include robbery with violence and armed robbery, theft of motor vehicles, frauds against the government, public corporations and private commercial or financial institutions, counter-

8 The DCI is also a Presidential nominee,http://www.tanzanianewsreports.com/\%EF\%BB\%BFtgnpfor-inclusive-parent-law-2/,(Accessed 17/08/2016).

9 Tibasana, M. Laurean, Effective Administration of the Police and Prosecution in Criminal Justice: The Practise and Experience of the United Republic of Tanzania, http://www.unafei.or.jp/english/p df/RS_No60/No60_19PA_Tibasana.pdf, pg. 168, (accessed 17/08/2016).

10 Ibid. 
feiting offences, burglary and stealing involving high value property, theft/illegal possession of firearms and cattle theft.

3. Crimes against social order is a rather broad category consisting of all victimless crimes like illicit drug abuse, illicit drug trafficking, possession of illicit drugs like cocaine, heroin, cannabis and so forth. Smuggling, possession of illicit liquor, illegal possession of government trophies. Corruption and offences related to the gemstone and precious stones industry also fall under this category.

4. Accidents involving rail, air and all forms of marine transport in other words ships, steamers, boats, dhows among others are also classified as serious incidents because of their potential impact in terms of loss of or injury to life. Road traffic accidents are not included in this category.

The Criminal Investigation Department is structured in the same way as the rest of the police force it forms part of. At Regional and District levels, the CID units are headed by Regional Crime Officers (RCO) and District Officers in charge of Criminal Investigation respectively. RCO's are answerable to Regional Police Commander (RPC) and similarly District Officer in charge of Criminal Investigation are answerable to the District Police Commanders (DPC). ${ }^{11}$

As can be noted from the structure below; the CID units have sub-offices designated specifically to investigate specific offences such as offences against property, person, human trafficking, financial and cyber crime to mention few.

11 Tibasana, M. Laurean, Effective Administration of the Police and Prosecution in Criminal Justice: The Practise and Experience of the United Republic of Tanzania, http://www.unafei.or.jp/english/p df/RS_No60/No60_19PA_Tibasana.pdf, pg.169, (accessed 17/08/2016). 
Structure of the criminal investigation department ${ }^{12}$

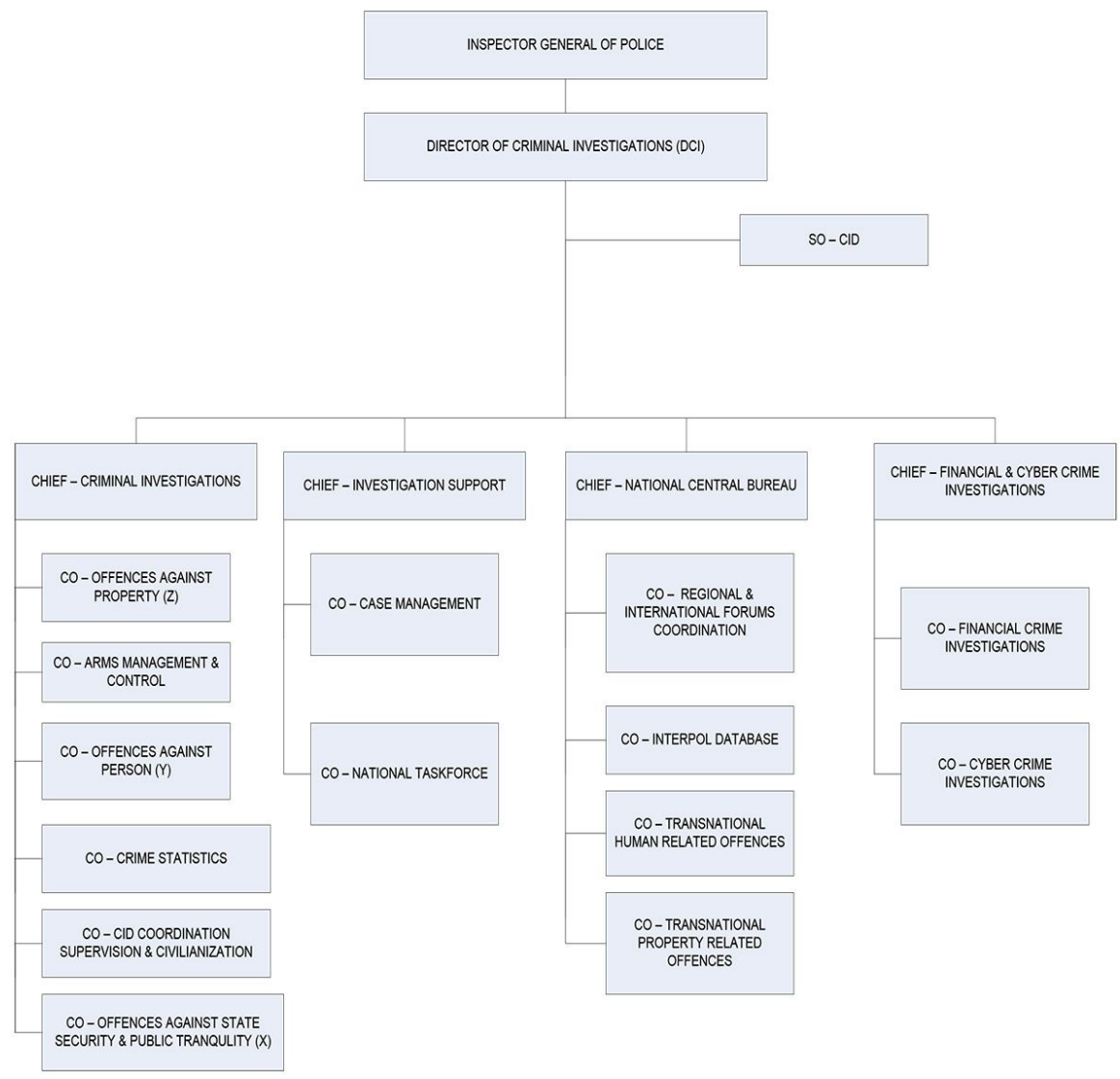

\section{The role of prosecutors in investigation}

In Tanzania, the task of prosecuting persons suspected of having violated the law is almost entirely undertaken by specific organs on behalf of the State. This is because; every act which constitutes to be a crime is as such, an offence not against the individual who may have been injured by it, but against the State. Where, therefore, an offence has been committed, it is not left to the will or ability of an individual to institute a prosecution, but such a prosecution is instituted by, and on behalf of the state through public prosecutors. Thus all criminal prosecutions are the direct concern of the Director of Public Prosecution (DPP)

12 Official website of the Tanzania Police Force, http://www.policeforce.go.tz/index.php/sw/kuhusu-s isi/muundo-wa-jeshi-la-polisi, (accessed on 16/08/2016). 
who is also a Presidential nominee. ${ }^{13}$ The DPP is assisted in the discharge of his/her functions by lawyers (State Attorney's). ${ }^{14}$

In order for the process of prosecution of suspects to function effectively and because of the paucity of State Attorney's the DPP has been vested with powers to appoint public prosecutors for Tanzania generally or for any specified category of cases. ${ }^{15}$ It is in the exercise of these powers that the DPP has appointed various other public officers to be Public Prosecutors. As such Labour Officers, Health Inspectors, Postal Officials and other public officers prosecute cases related to their occupations. Public Prosecutors appointed however remain subject to the directions of the DPP in the conduct of the prosecution. ${ }^{16}$

In exercise of the same powers referred to above, the DPP has appointed every police officer not below the rank of Assistant Inspector of Police to be a Public Prosecutor. ${ }^{17}$ However, it was observed that to let the same person arrest, investigate and prosecute might led to mischariage of justice.

To avoid mischarriage of justice, the role to prosecute in most areas of the country is now dealt with State Attonery's as their number has also increase but other parts of the country still retain police prosecutors especially areas where state attorney's offices have not been established. But the plans is to leave the prosecutorial role to State Attorney's.

Apart from the responsibility to dispose criminal cases for prosecution, prosecutors in Tanzania, do not investigate but led the investigation process by giving advice, opinion, guidance, instruction and supervision to the police investigator for them to carry out investigation to certain direction.

Accordingly, the police are the ones empowered to conduct investigations and the prosecutors check the investigation conducted by the police and dispose the case for prosecution. In other words, prosecutors are vested with the responsibility of checking the police investigation against due process of law.

\section{Collaboration between the police investigators and prosecutors}

This part discusses the collaboration between the police investigators and prosecutors in the investigation process. The foremost areas of collaboration discussed herein below includes; provision of advice, opinion, guidance giving, supervision and/ or instruction and finally making of the decision to prosecute.

13 Section 89 of Criminal Procedure Act No. 9 of 1985.

14 Section 5(1) of the National Prosecutions Service Act, 2008.

15 Section 95of Criminal Procedure Act No. 9 of 1985 [Repealed by Section 27 of the National Prosecutions Service Act, No.27 of 2008].

16 Tibasana, M. Laurean, Effective Administration of the Police and Prosecution in Criminal Justice: The Practise and Experience of the United Republic of Tanzania,http://www.unafei.or.jp/english/p df/RS_No60/No60_19PA_Tibasana.pdf, pg. 171, (accessed 17/08/2016).

17 Criminal Procedure (Public Prosecutors) Order. Government Notice No. 382 of 1943. 


\section{Provision of advice/ opinion and making the decision to prosecute}

A case in Tanzania normally goes through four main stages and each is characterised by the number of activities as follows;

- reporting by the victim of the crime,

- gathering of evidence by the investigators,

- the reading or study of the case file

- and the making of the decision to prosecute

Upon receiving a report by the victim or any person who may be aware of the crime, the police officer receiving the report decides whether the report discloses any offence and if so, which offence. Thereafter evidence is gathered and where need arise, the scene of crime is then visited to appreciate the circumstances of the event. A senior officer supervises and guides the investigation by issuing appropriate instructions to the investigator(s).

Depending on the complexity of the case, the collection of evidence can take a long or short period of time and at some stage the suspect will be arrested, if he/she was not arrested immediately after the commission of the crime.

If the supervisor is satified with the investigation, the case file is presented to the RCO (Regional Crime Officer) or DO-CI (District Officer in charge of Criminal Instigation) to be studied. The RCO weight the provisions of the law against the facts discovered by the investigator. Then the case files are reffered to the State Attorney's office (prosecutor's) for evaluation.

The prosecutor (state attorney) evaluates/studies the case files and give out their opinion, advice or instruction regarding the evidence collected. Prosectuors mainly evaluates if the evidence gathered is sufficient and sees how it fit to the court proceedings. If find out that more evidence needs to be collected, they comment on the case file or may comment for stay of the proceeding if not satisfied with the evidence supporting the charges and order release of the accused if in custody. Morever, if prosecutor's are satisfied with the evidence they recommend the matter to be taken to court by issuing a charge sheet.

The case files are then taken back to the investigator (police) for action as recommended by the procesutor. The collaboration between the police investigator and prosecutor continues until the final determination of the case.

Most cases accused persons are taken to court for mentioning of their case, while investigations are ongoing thus within such a period the two authorities keep on collaborating. But also after prosecution, feedback on the court decisions is given by the prosecutor to the RCO DO-CI heads of Criminal Invesigation Departments.

\section{Giving guidance/instructions to police investigators}

Noted from above, one of the most important and common roles of prosecutors is to check police investigations against due process of law, while keeping the effectiveness of police investigation. To meet the rule of law standards, promote acceptance of court decision by 
the accused and strengthen public confidence in the police's right to conduct searches and seizures in private premises, the investigation work of the Police is at least in principle, critically monitored by the Prosecutors' authorities through supervising and giving guidance/ instructions to police investigators.

\section{Supervision and co-ordination}

The structure of the Criminal Investigation Department as discussed earlier consists of Regional Crime Officers and District Officers in charge of Criminal Investigation at the regional and district levels. These officers supervise the criminal investigation units and they are answerable to the Regional Police Commander (RPC). Public prosecutors in the police force fall under the general supervision of Regional Crime Officers, the principal supervisors of crime investigation at regional level. They are however expected to co-ordinate their work with other officers such as officers in charge of Police Stations (OCS) where the cases submitted to them for prosecution originates directly from.

As noted earlier, minor offences are normally investigated by investigators from the General Duties Branch i.e uniformed officer and serious offences are investigated by detectives from CID units. While the coordination of the investigation into minor offences where such need arises will be the responsibility of the officers in charge of stations, prolonged investigations requiring thorough collection of evidence is done by the CID units. It is thus not uncommon for cases begun by the uniformed branch to be transferred to detectives in the CID units. Indeed, one of the terms of the mandate of the Director of Criminal Investigation in exercise of his/her discretion is to take over the investigation of any crime where deemed expedient to do so. The Director of Criminal Investigation will in befitting cases, instruct Regional Crime Officers to act in that regard. This perhaps ties up the equation. With the Public Prosecutor and the investigator both falling under the supervision of the Regional Crime Officer, one may conclude that it is his/her duty to coordinate both the process of investigation and the conduct of the prosecution. ${ }^{18}$

\section{Other areas of collaboration}

Prosecutors are suppose to vist the scene of crime where necessary, for them to be able to give out advice on the kind of evidence to be collected to support a charge. But rarely this happens due to lack of resources like transport.

The prosecutor also visit the custody's as away of supervising the work of the investigator to ensure it is inline with the legal guideline and procedures of criminal investigation. For instance observing hours of arrest for accuse and hours of interrogation.

18 Tibasana, M. Laurean, Effective Administration of the Police and Prosecution in Criminal Justice: The Practise and Experience of the United Republic of Tanzania, http://www.unafei.or.jp/english/p df/RS_No60/No60_19PA_Tibasana.pdf,pg. 173, (accessed 17/08/2016). 
Joint quarterly meetings between investors and prosecutors are held to discuss cases, give each other advice and raise any issues concering their working realtions.

\section{E. Current issues regarding the collaboration of investigative authorities in Tanzania}

This section highlights some of the inevitable conflicting reactions and tendencies which hamper the smooth collaboration between the police investigators and prosecutors in the investigation process.

\section{Psychological traits of the police and prosecutors ${ }^{19}$}

After undergoing lengthy, laborious and complicated investigations process, police investigators generally tend to develop a feeling of exclusiveness, and feel that the entire investigation domain is their responsibility. As a result any sort of advice and instruction from outside is taken as interference and unnecessary. Resistance is shown if they are told to bring more substantial evidence, or amend or improve the evidence collected.

Though the police (investigators) work and do the investigation within their own legal and procedural codes, their practical and operational framework makes them believe that they have their own chain of command system which works as efficiently as prosecutorial agencies and which they believe, can provide them guidance and instructions.

On the other hand, with academic background in jurisprudence hence having greater sensitivity of human rights, rule of law and due process, prosecutors tend to develop more legalistic approach in handling police files. Prosecutors first examine the appropriateness of evidence and will then evaluate its fitness for the court proceedings. Pressure from colleagues in an investigating agency for prosecution may embarrass him in case his disposition appears to lead to acquittal. Similarly, investigators may bring applications for arrest warrants to a prosecutor and ask for speedy scrutiny, which will put pressure and strain on the prosecutor.

These mutually repellent psyches of investigators and prosecutors have hampered the smooth working relationship between the two. ${ }^{20}$

19 "Cooperation between the police and prosecutors" in their consideration of "effective Administration of the Police and the Prosecution in Criminal Justice". 12Oth UNAFEI International Senior Seminar report of $2001 \mathrm{http} / / /$ www.unafei.or.jp/english/pdf/RS_No60/No60_ 00All.pdf, pg. 196, (accessed 17/08/2016).

20 Ibid pg. 197. 


\section{Conflicting views over case disposition ${ }^{21}$}

The police feel frustrated when the prosecutors' case-disposition conflicts with the expectations of the police. It is totally disappointing for investigators if an arrested suspect is set free by prosecutors on the ground that the prerequisites have not been fulfilled for keeping the suspects in custody, or where investigatory activity despite the great deal of time and effort involved leads to the termination of proceedings.

Prosecutors also feel stressed, which may lead to negative influence on the working relation between the two.

\section{Lack of shared common goals ${ }^{22}$}

A lack of sharing common goals in criminal proceedings, as such cause difficulty for prosecutors to motivate police to produce quality files on their investigation.

In such cases, the police may develop practices, which are not compatible with the prosecutorial process, such as relying only on information that is not admissible as evidence in the court.

\section{Lack of objectivity ${ }^{23}$}

As some prosecutors are full time members of the police department themselves, and wear same police uniforms and share the same hierarchical chain of command structure as their colleague investigators, they feel inhibited to write an advice, which may substantially affect the investigations. A lack of appropriate supervision of and guidance to investigations in such a system may also result in low conviction rate in the court.

\section{Other challenges}

Other challenges which hamper the smooth working relation between the two authorities include; police failure to implement prosecutors advice, poor collaboration and carelessness in carrying out further investigation and prolonged investigation of which, all may lead to dismisal of cases.

\section{F. Recommendations and Conclusion}

In Tanzania the authority to investigate is primarily vested to the police. In discharging the investigative duty, the police are assisting the prosecutor and the court to dispense jus-

21 Cooperation between the police and prosecutors" in their consideration of "effective Administration of the Police and the Prosecution in Criminal Justice,Ibid, pg. 197.

22 Ibid.

23 Ibid. 
tice. The police are thus duty bound to collaborate with the prosecutors and other relevant authorities in the investigation process. However, the collaboration between them is limited to advisory role. Prosecutors have no role in the investigation as such, but do exercise their advisory or supervisory role to guide the police investigation against due process of the law. Inevitably, conflicting reactions and tendencies arises in the course of the collaboration which hamper their smooth working relationship. Such conflicts should be considered as evidence for the proper functioning of the checks and balance mechanism of the criminal justice system.

The following are recommendations to prompt a smooth working relationship;

I. The police should welcome, or at least try not to avoid, such checks from prosecutors. On the other hand, the prosecutors' supervisory functions such as giving advice/ instructions to police investigators should always be accompanied with clear and reasonable explanations of their grounds.

II. Both sides should make efforts to understand and respect each other's responsibility in criminal procedure. The police should respect the prosecutors' advice with a view to sustain successful prosecution, and try their best to protect the due process of law in the course of their investigation. Prosecutors should try to understand the difficulty the police are facing in the course of police investigations and to pay as much respect as possible, within existing legal framework to the discretion of the police in their investigation.

III. Effective criminal justice management requires concerted action of all relevant authorities in the government, which have the same ultimate goal of realisation of the rule of law. Such authorities should share substantial common values such as joint business plan for criminal justice system. Such notion of joined-up working should surely promote practical cooperation between the police and prosecutors.

IV. Intensive consultation with the police about matters arising in connection with a particular investigation reduces police frustration about releasing the accused or about subsequent termination of the proceedings, and leads to better results in the investigation, because there can then be precise determination in advance of what is actually needed for the purpose of preparing the main hearing. The motivation for efficient collaboration between police investigators and prosecutors cannot be overstated in relation to the goal of avoiding, or at least reducing, frustration experience by the police.

V. Regular meetings between police and prosecutors might lead to coordination and simplified investigations. Workshops and seminars should be used to exchange views on areas of contention in order to forge closer working relationship. During those seminars sensitization should be done to ensure both prosecutors and police understand that they are set for the same purpose to combat crime. 


\section{Reference}

\section{Acts and Government Notice}

The Constitution of the United Republic of Tanzania, 1977 (as amended from time to time)

The Police Force Ordinance Cap. 322

Criminal Procedure Act No. 9 of 1985

The National Prosecutions Service Act, 2008

Criminal Procedure (Public Prosecutors) Order. Government Notice No. 382 of 1943

\section{Book}

Kamau, Evelyn, The police, the people, the politics; police accountability in Tanzania, Commonwealth human rights initiative, (2006),https://books.google.co.tz/books/about/The_Police_the_Peo ple_the_Politics.html?id=DF9wsKfDOgQC\&redir_esc $=y($ accessed on 17/08/2016)

Stroud's Judicial Dictionary of Words and Phrases, South Asian Edition, (2008), $7^{\text {th }}$ Edition Volume 1 A-E

\section{Web}

http://law.jrank.org/pages/1654/Police-Criminal-Investigations-Criminal-investigation-defined.html http://www.policeforce.go.tz/index.php/sw/kuhusu-sisi/vyeo-vya-jeshi-la-polisi http://www.tanzanianewsreports.com/\%EF\%BB\%BFtgnp-for-inclusive-parent-law-2/ http://www.unafei.or.jp/english/pdf/RS_No60/No60_19PA_Tibasana.pdf 